\title{
Blattaria from Museu de La Plata, Argentina: New records for Blaberus affinis Jurberg, Albuquerque, Rebordões, Gonçalves \& Felippe, 1977 and Blaberus scutatus Saussure \& Zehntner, 1894 (Blaberidae, Blaberinae)
}

\author{
Sonia Maria Lopes ${ }^{1 *}$ \& Mariana Assumpção $o^{I}$ \\ ${ }^{1}$ Universidade Federal do Rio de Janeiro, Museu Nacional - Entomologia, Quinta da Boa Vista, \\ Rio de Janeiro, RJ, Brazil \\ *Corresponding author: Sonia Maria Lopes, e-mail: sonialfraga@gmail.com
}

LOPES S. M., ASSUMPÇÃO, M. Blattaria from Museu de La Plata, Argentina: New records for Blaberus affinis Jurberg, Albuquerque, Rebordões, Gonçalves \& Felippe, 1977 and Blaberus scutatus Saussure \& Zehntner, 1894 (Blaberidae, Blaberinae). Biota Neotropica. 17(3): e20170381. http://dx.doi.org/10.1590/1676-0611-BN-2017-0381

\begin{abstract}
The habitus of the males of seven species of Blaberus that belong to the Blattaria collection of the La Plata Museum from Argentina (of which two are new occurrences for the country) are illustrated and are classified into the appropriate groups. Information on their collection sites, synonyms and updated geographic distribution is also provided. In total, 27 Blaberus specimens were studied and will be returned to the collection of the Entomology from the Museu de La Plata, Buenos Aires, Argentina.
\end{abstract}

Keywords: Collection, La Plata Museum, Blattaria, new records.

\section{Blattaria do Museu de La Plata, Argentina: Novos Registros para Blaberus affinis Jurberg, Albuquerque, Rebordões, Gonçalves \& Felippe, 1977 and Blaberus scutatus Saussure \& Zehntner, 1894 (Blaberidae, Blaberinae)}

\begin{abstract}
Resumo: Os habitus dos machos de sete espécies de Blaberus que pertencem ao Museu de La Plata na Argentina (dos quais duas são novas ocorrências) são ilustrados e assinalados em grupos apropriados. Informação sobre seus locais de coleta, sinonímias e sua distribuição geográfica atual são também citadas. No total, 27 espécimens de Blaberus foram estudados e serão acondicionados à Divisão do Museu de La Plata, Buenos Aires, Argentina.
\end{abstract}

Palavras chave: Coleção, Museu de La Plata, Blattaria, nova ocorrência.

\section{Introduction}

The genus Blaberus was described by Serville (1831), who designated Blatta giganteus Linnaeus, 1758 as type-species. The males of the genus have the following characteristics: large individuals, 45-88 $\mathrm{mm}$; usually with small cerci, not reaching the posterior margin of the supranal plate; subgenital plates with two similar styles, simple, and small, genital hook on the right side. Females with atrium enlarged, where the eggs are incubated. In a literature review of the genus, Lopes \& Oliveira (2013) listed 20 species, including them into three groups that were based on the male internal genitalia: the atropos, brasilianus and giganteus groups. They also described one new group based on the female (macurus group). Intra and interspecific variations among the species were defined with respect to habitus, morphology of the head and the pronotum, and genital characters. The following species were included in the atropos group: B. amazonensis Lopes \& Oliveira, 2013, B. atropos (Stoll, 1813), B. colombianus Lopes \& Oliveira, 2013, B. duckey Jurberg et all, 1977, B. parabolicus Walker, 1868, B. paulistanus Lopes \& Oliveira, 2000, B. matogrossensis Rocha e Silva \& Aguiar, 1977, B. neomatogrossensis Lopes \& Oliveira, 2013,
B. peruvibolicus Lopes \& Oliveira, 2013 and B. yuracianus Lopes $\&$ Oliveira, 2013. In the brasilianus group, the following species were included: B. affinis Jurberg, R. S. Albuquerque, Rebordões, Gonçalves \& Felippe, 1977, B. chacoensis Lopes \& Oliveira, 2013, B. neofusiformis Lopes \& Oliveira, 2013, B. parafusiformis Lopes \& Oliveira, 2013, B. nigrocephalicus Lopes \& Oliveira, 2013, B. scutatus Saussure \& Zehntner, 1894, B. valleyanus Lopes \& Oliveira, 2013. No grupo giganteus are included $B$. giganteus (Linnaeus, 1758), B. nigromaculatus Lopes \& Oliveira, 2013. Roth (1969) also included B. minor Saussure, 1864 in brasilianus group.

Beccaloni (2014), in his "on line" catalog, listed only 19 species in the genus.

In this contribution, the habitus of the males of seven species of Blaberus are illustrated and the species are assigned to one of the following groups 1 ) the atropos group (B. atropos, B. neomatogrossensis) and 2) the brasilianus group (B. affinis, B. scutatus, B. neofusiformis, $B$. parafusiformis and $B$. minor). Two new records for $B$. affinis and $B$. scutatus are given. The collection sites, synonyms and updated geographic distribution are also provided. 


\section{Material and Methods}

The specimens were analyzed morphologically following routine techniques developed in the laboratory and described by Lopes \& Oliveira (2000). The terminology for the genital parts, literature and taxonomic classification were based on Roth (1970, 1976 and 2003). The phylogenetic position of the genus follows Khambhampati, 1995 and Klass \& Meier, 2006. After analysis, the genital parts were stored in microvials containing glycerin and were stored next to the specimen on the same entomological pin, following Gurney et al (1964). In total, 27 Blaberus specimens were studied and identified and will be returned to the collection of the Entomology of the Museu de La Plata, Buenos Aires, Argentina (MLP).

\section{Results}

1) The atropus group- species in this group lack a hook shaped or tumor-like growth at the apex of the median sclerite (Roth 1976). Truncated or rounded projections or crests are present only of the left side of the prepuce, which are much larger than the spines of the right side. Preputial spines are often arranged in a single series, but may also be in a double or partially double series on the right side, in which case they are more numerous than those on the left side.

\section{Blaberus atropus (Stoll, 1813)}

(Figure 1a)

B. atropos Stoll, 1813:4 (Blatta); Saussure, 1864: 233-234; Brunner von Wattenwyl, $1865: 22,23,40,44,372,375,376,377,410,415$; Walker, 1868: 2, 4, 5, 6, 7; Saussure \& Zehntner, 1894: 118; Rehn, 1903:131,288; Kirby, 1904:164; Hebard, 1921:217; Rehn \& Hebard, 1927:261-162; Hebard, 1931; Princis, 1946:145-146; Princis \& Kevan, 1955:159, 167; Princis, 1958:75; Bruijning, 1959: 3,6-7; Princis. 1963:131-132; Rocha e Silva-Albuquerque, 1964:5; Vanschuytbroeck, 1969:5; Roth, 1969:217-250; Rocha e Silva, 1982:3; Beccaloni, 2014 http://blattodea.speciesfile.org; Grandcolas, 2008:43; Lopes \& Oliveira, 2013:82

Material examined: $1 \delta$ e 1 우 Venezuela, Delta Amacuro, Araguaimujo, 12/VIII/1964, without collector.

Distribution: São Domingos, Jamaica, Guyana, Suriname, Trinidad, Tobago bay, Cuba, Mexico, Venezuela, Colombia, Chile, Brazil (Rio de Janeiro, Rondônia, Amazonas, Pará, São Paulo).

Blaberus neomatogrossensis Lopes \& Oliveira, 2013

(Figure 1b)

Blaberus neomatogrossensis Lopes \& Oliveira, 2013:86

Material examined: Paratypes 2 $\widehat{\jmath}$, Venezuela, Guárico, S. Juan de los Morros, Cuevas de Los Morritos, 3/IX/1961, Bordon col.

Distribution: Brazil (Mato Grosso); Venezuela (Guárico).

2) The brasilianus Group - This group includes species whose male genitalia lack a hook-shaped projection or a tumor-like growth. The prepucial spines are numerous on the left and right sides and are generally arranged in a row.

Blaberus affinis Jurberg, R.S. Albuquerque, Rebordões, Gonçalves \& Felippe, 1977

(Figure 1c)

B. affinis Jurberg, R.S. Albuquerque, Rebordões, Gonçalves \& Felippe, 1977: 539-540, figs. 5-15; Lopes \& Oliveira, 2000:3; Beccaloni, 2014. http://blattodea.speciesfile.org>; Pellens \& Grandcolas, 2008:49; Lopes \& Oliveira, 2013:88

Material examined: $1 \delta$ Argentina, Salta, Dto. Victoria, 17/VII/1933, P. Denier col.

Distribution: Brazil (Rio de Janeiro, Mato Grosso, Goiás, São Paulo).

New record: Argentina, Brazil (Ceará, Sergipe).
Blaberus parafusiformis Lopes \& Oliveira 2013

(Figure 1d)

Blaberus parafusiformis Lopes \& Oliveira, 2013:90

Material examined: $1 \overbrace{}^{\lambda}$, Paratype. Brazil. Mato Grosso, without data, Museu de La Plata, Scardinsky col.

Distribution: Brazil (Mato Grosso, Rio de Janeiro, São Paulo, Rondônia, Goiás) Argentina.

Blaberus minor Saussure, 1864

(Figure 1e)

Blaberus minor Saussure, 1864:347; Beccaloni, 2014.http://blattodea. speciesfile.org>

B. fraterna Saussure, 1864-65: 238-242; Walker, 1868:2-7; Kirby, 1904: 165; Hebard, 1931:261; Princis, 1963:130; Roth, 1970:312-313, 319; Jurberg; R.S. Albuquerque; Rebordões, Gonçalves \& Felippe, 1977:545-547 Princis, 1963:130; Pellens \& Grandcolas, 2008:50; Beccaloni, 2014.http://blattodea speciesfile.org>

Material examined: $1 \delta^{\Uparrow}$ Argentina (Formosa), 31/10/1940, P. Denier col. Distribution: Brazil, Paraguay, Argentina and Bolivia
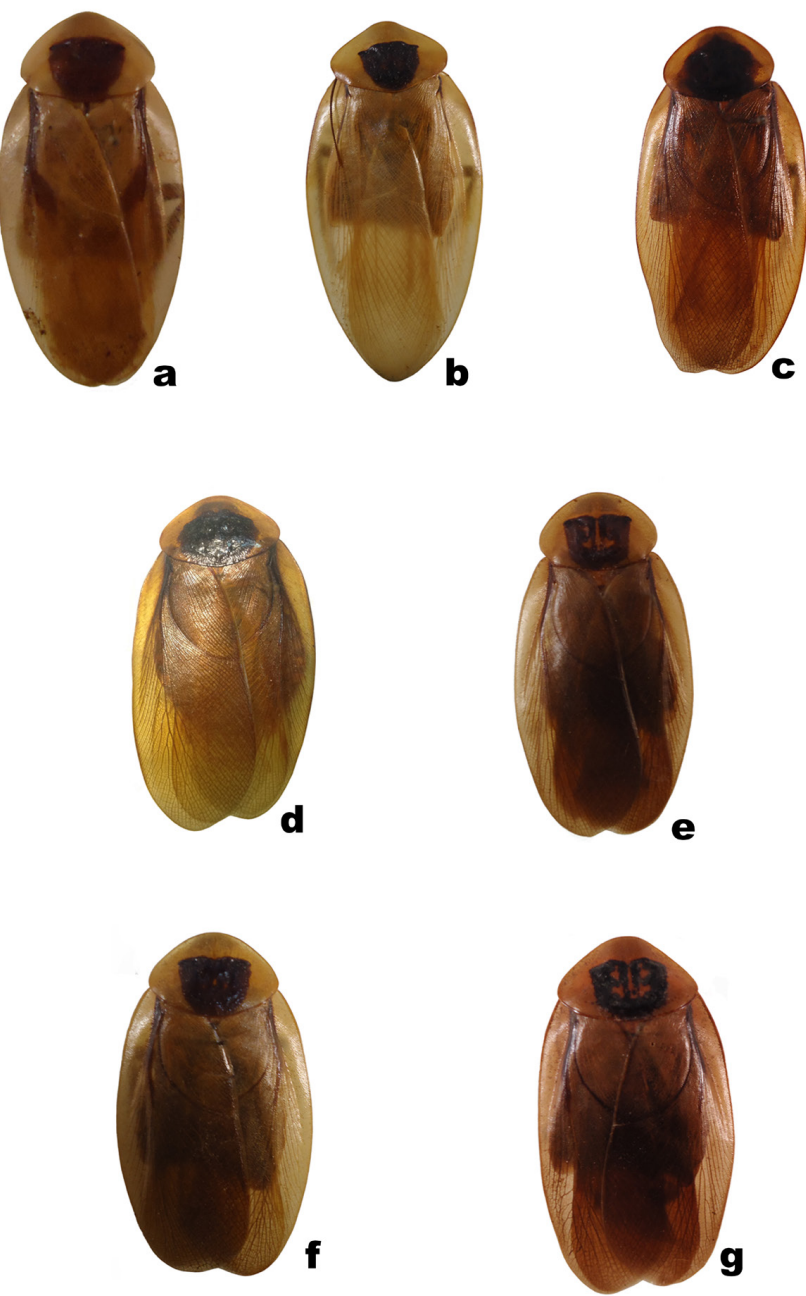

Figures 1 Habitus. a. Blaberus atropos (Stoll, 1813); b. Blaberus neomatogrossensis Lopes \& Oliveira, 2013; c. Blaberus affinis Jurberg, R.S.Albuquerque, Rebordões, Gonçalves \& Felippe, 1977; d. Blaberus parafusiformis Lopes \& Oliveira, 2013; e. Blaberus minor Saussure, 1864; f. Blaberus neofusiformis Lopes \& Oliveira, 2013; g. Blaberus scutatus Saussure \& Zehntner, 1894. 
Blaberus neofusiformis Lopes \& Oliveira, 2013

(Figure 1f)

Blaberus neofusiformis Lopes \& Oliveira, 2013:89

Material examined: $1 \hat{\jmath}$ Paratype. Argentina, Jujuy, 23-28/II/1945, Biraben col.; $1 \widehat{\delta}$ Paratype, Argentina, Salta, Juramento, Dept. Robles, 02/XI/1939; $1 ð$ Paratype, Argentina, Salta, Orán, 5/VI/1947, Denner

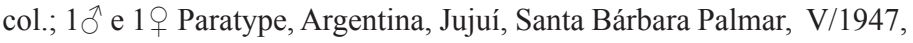
Biraben col.

Distribution: Brazil (Ceará, Pernambuco, São Paulo, Goiás), Argentina

Blaberus scutatus Saussure \& Zehntner, 1894

(Figure 1g)

B. scutatus Saussure \& Zenhtner, 1894:119 (Blabera); Princis, 1963:132; Rocha e Silva-Albuquerque, 1964:5; Roth, 1969:220-221,228; Vanschuyetbroecker, 1969: 6; Roth, 1970:312, 319; Beccalloni, 2014: http://blattodea.speciesfile.org; Pellens \& Grandcolas, 2008:44; Lopes \& Oliveira, 2013:92

Material examined: $1 \hat{\jmath}$ Argentina, Salta, Juramento, 02/XI/1939, without collector; $2 \widehat{\diamond}$ Argentina, Corrientes, 15-30/II/1959, Biraben col.; $1 \widehat{\partial}$ Argentina, Formosa, Mojon de Fierrro, 11/XII/1939. P. Denier col.; 1 ㅇ Argentina, Formosa, 15/XI/1942, M. Birabén col.; 20 Argentina, Estancia de La Amalia, Resistencia Chaco, 13/IX/1955, E. Martin M. Calvan col.; $1 \delta$ Argentina, Chaco, XII/1913. M. Currens Leg; $2 \hat{\delta}$ and $2 q$ Argentina, Chaco, Estancia Anello, Cam a. Zapallar 10-15/III/1959, Birabén col.; $2 \widehat{o}$ e 2 . . Argentina, Córdoba, Los Cocos "El Piquillin", 17/II/1944, Sta Pritchard; 10 . Argentina, Museu de La Plata.

Distribution: BRAZIL (Piauí, Ceará, Minas Gerais, Rio Grande do Norte, Pernambuco, Sergipe, Bahia, Rio de Janeiro), Peru, Paraguay.

New record: Argentina

\section{Author Contributions}

Sonia Maria Lopes: substantial contribution in the concept and design of the study; contribution to data analysis and interpretation; contribution to manuscript preparation and critical revision.

Mariana Assumpção: substantial contribution in the concept and design of the study.

\section{Conflicts of interest}

The authors declares that they have no conflict of interest related to the publication of this manuscript.

\section{References}

BECCALONI, G.W. 2014. Cockroaches Species File Online. Version 5.0/5.0. World Wide Web electronic publication. <http://blattodea.speciesfile.org> [accessed 17/01/17].

GURNEY, A.B., KRAMER, J. P. \& STEYSKAL, G.C. 1964. Some Techniques for the Preparation, Study and Storage in Microvials of Insect Genitalia. Annals of the Entomological Society of America, Washington 57(2):240-242.

KHAMBHAMPATI, S. 1995. A phylogeny of cockroaches and related insects based on DNA sequence of mitochondrial ribosomal RNA genes. Proceedings of the Academy of Natural Sciences of Philadelphia 92:2017-2020.

KLASS, K.D. \& MEIER, R. 2006. A phylogenetic analysis of Dictyoptera (Insecta) based on morphological characters. Entomologische Abhandlungen 63:3-50. Konowia 10: 257-285.

LOPES, S.M. \& OLIVEIRA, E.H. 2000. Espécie nova de Eublaberus Hebard, 1919 do Estado de Goiás, BRASIL e notas sobre E. marajoara Rocha e SilvaAlbuquerque, 1972 (Blaberidae, Blaberinae). Boletim Museu Nacional Rio de Janeiro, Nova Série, Zool. 433:1-5.

LOPES, S.M. \& OLIVEIRA, E.H. 2013. New group, new species and new records from Brazil of the atropos, brasilianus and giganteus groups (Blattaria, Blaberidae, Blaberinae). Biota Neotropica, vol. 13, no. 2 (on line)

ROTH, L.M. 1969. The male genitalia of Blattaria I. Blaberus spp. (Blaberidae Blaberinae. Psyche 76 (3): 217-250

ROTH, L.M. 1970. The male genitalia of Blattaria IV. Blaberidae: Blaberinae. Psyche 77(2):217-236.

ROTH, L.M. 1976. The male genitalia of Blattaria. I. Blaberus spp. (Blaberidae: Blaberinae). Psyche 76: 217-250

ROTH, L.M. 2003. Systematics and Phylogeny of Cockroaches (Dictyoptera, Blattaria). Oriental Insects 37: 1-186.

SERVILLE, J. G.A. 1831. Revue méthodique des insectes de l'ordre des Orthoptères. Annales des Sciences Naturelles, Zoologie et Biologie Animale 22: 166-167.

Received: $21 / 05 / 2017$

Revised: 28/08/2017

Accepted: $31 / 08 / 2017$

Published online: 05/10/2017 